\title{
Use of Exophytic Microbial on the Control of Fruit Rot Disease of Mango (Lesiodiplodia theobromae)
}

\author{
I Made Sudarma*, Ni Wayan Suniti and dan Ni Nengah Darmiati
}

Lecturer staff at the Agroecotechnology Study Programe, Faculty of Agriculture, Udayana University, Jl. PB. Sudirman Denpasar, Bali, Indonesia

*Corresponding author

Ke y w o r d s
Mango rot,
Exophytes,
Lesiodiplodia
theobromae,
Inhibition ability, in
vitro and in vivo
Article Info
Accepted:
10 March 2020
Available Online:
10 April 2020

Keywords

Mango rot,

Exophytes,

Lesiodiplodia

theobromae,
A B S T R A C T

Post-harvest mango rot is the main cause of yield loss caused by this disease in Bali. Until now, no environmentally friendly control methods have been found such as finding exophyte microbes that are antagonistic to pathogens. The pathogen found to cause fruit rot disease in mangoes is Lesiodiplodia theobromae. Exophytic fungi found in healthy mangoes include: Rhizopus sp. the number of colonies $24 \times 10^{2} \mathrm{cfu}$, while Nucordia sp., A. flavus, and A. niger with colonies $18 \times 10^{2} \mathrm{cfu}$ each, and Streptomyces sp. with a colony of $12 \times 10^{2} \mathrm{cfu}$. The highest in vitro microbial inhibitory test results of $L$. theobromae were obtained from Rhizopus sp. 1 and Rhizopus sp. 4 when 4 hsi and 7 hsi. The results of antagonistic inhibition test on pathogens (L. theobromae) in vivo obtained the highest by the treatment of $\mathrm{C}$ (Rhizopus sp. 3) which was very significantly different from $\mathrm{K}+\mathrm{P}$ (control with pathogens).

\section{Introduction}

Post-harvest fruit rot is often found during marketing, storage, when consumption is very disturbing in the appearance of damaged fruit and affects the taste of the fruit. Mangoes are very important for tropical countries and subtropics (Prakash et al., 2011), moreover for Indonesia, although mangoes are affected by a number of diseases but are some important diseases and are responsible for yield loss in mango production. There are several diseases that attack post-harvest mangoes, among others: anthracnose, fruit base rot, black rot.

Botryosphaeria rot, stem rot and soft rot, chocolate rot, Pestalotiopsis rot, Charcoal rot, Phoma rot, Alternaria rot, Macrophoma rot, Macrophoma rot, Rhizopus rot, Cladosporium rot, Fusarium rot, Canariomyces rot, Mucor rot, Alternate rot, Macrophoma rot, Ash rot, 
Rhizocia ash, Rhizocia rot, Ash rot Hendersonia rot, blue mold, runny soft rot, Sclerotium fruit rot and Yeasty rot (Prakash $e t$ al., 2011). Many cases are found in the field of disease but the method of control until now has not been known to be environmentally friendly.

An exophytic fungus is a surface fungus that can live saprophytic but does not cause disease in plants. Phyloplan fungi are mycota that grow on plant surfaces (Langvard, 1980). There are groups of phyloplan mushrooms: resident (stay silent) and casual (coincidence). Resident can multiply on the surface of healthy leaves without being noted to affect the host while casual landed on the surface of the leaf but cannot grow (Leben 1965). The results of Sudarma et al., (2019) stated that exophytic and endophytic fungi can suppress the ability of pathogens in red grape both in vitro and in vivo.

\section{Materials and Methods}

\section{Place and time of research}

The study was conducted in two places: 1) looking for sick and healthy fruit specimens from the Batubulan and Supermarkets markets. 2) Plant Disease Laboratory and Agricultural Biotechnology Laboratory. The study was conducted in January to March 2020 .

\section{Microbial isolation of exophytes}

Isolation of exophyte microbial can be done by dipping the mango into $250 \mathrm{ml}$ of water, then shaking it and rinsing it evenly. This washing water as much as $250 \mathrm{ml}$ is used as a dilution of the microbial population found. Furthermore, $1 \mathrm{ml}$ is taken poured into a Petri dish which is first filled with a PDA media PDA and added anti-bacterial livoploxacin at a dose of $0.1 \%(\mathrm{w} / \mathrm{v})$.

\section{Identification of exophytic microbes}

The stored exophyticmicrobes were then grown on a Petri dish containing a PDA and repeated 5 times. Culture is incubated in a dark room at room temperature $\left( \pm 27^{\circ} \mathrm{C}\right)$. Isolates were identified macroscopically after 3 days of age to determine colony color and growth rate, and microscopic identification to determine septa in hyphae, spore/conidia and sporangiophores. Fungal identification using the reference book Samson et al., 1981; Pitt and Hocking, 1997; Barnett and Hunter, 1998; and Indrawati et al., 1999.

\section{Pathogen identification by PCR and sequencing}

Detection was carried out through the stages of extraction of the total DNA of the fungus using the DNeasy Plant Mini Kit (Qiagen/Germany).

\section{Stages of DNA extraction}

0.1 gram of sample was crushed using pistil and mortar until smooth then put in $1.5 \mathrm{ml}$ micro tubes and added $400 \mu 1$ of AP1 buffer and $4 \mu \mathrm{l}$ of RNase A stock solution then on vortex to homogenize the solution, then the tube containing the mixed solution was incubated for 10 minutes in a water bath with a temperature of $65^{\circ} \mathrm{C}$, and the tubes are turned upside down every 5 minutes, $130 \mathrm{ml}$ of AP2 buffer is added to the mixed solution and then it is vortexed and incubated in the refrigerator for 5 minutes.

After that, centrifugation was carried out at $14,000 \mathrm{rpm}$ for 5 minutes. Supernatant (top phase) produced at this stage was then pipetted and put into DNeasy Mini spin column (white color), and centrifuged at $14,000 \mathrm{rpm}$ for 2 minutes, the fraction in the lower tube (collection tube) moved into a new tube $(2 \mathrm{ml})$ without including the formed 
pellet, then added 1.5 AP3/E buffer volume and mixed using a pipette (by sucking and removing the mixture using a micropipette), after that piping as much as $650 \mu \mathrm{l}$ the mixture, including when a precipitate formed, was put into a DNeasy mini spin column (white in color) and centrifuged for 1 minute at $8000 \mathrm{rpm}$. The liquid in the $2 \mathrm{ml}$ collection tube is discarded. This stage can be repeated for the remainder of the mixture, then the collection tube is discarded with the liquid inside.

Next DNeasy mini spin column (white) is placed on a new micro tube that is already available, added 500 ul AW AW buffer and centrifuged at $8000 \mathrm{rpm}$ for 1 minute. The solution in the tube was discarded. Another $500 \mu \mathrm{l}$ AW buffer was added to the DNeasy Mini Spin Column, then centrifuged for 2 minutes at $14,000 \mathrm{rpm}$, then transferred the DNeasy Mini Spin Column to a new $1.5 \mathrm{ml}$ tube, added $100 \mathrm{ul}$ of $\mathrm{AE}$ buffer and put directly into the DNeasy membrane, incubated at room temperature for 5 minutes, then centrifuged for 1 minute at $8000 \mathrm{rpm}$, the resulting DNA can be directly used or stored at $-20^{\circ} \mathrm{C}$ until it will be used. Furthermore, the DNA produced is used as a template for PCR. The composition of the PCR reaction is: $1 \mu \mathrm{l}$ DNA template added to the PCR reaction mixture consisting of: $12.5 \mu \mathrm{l} 2 \mathrm{x}$ Dream Taq Green PCR Master Mix (Thermo Scientific), each $1 \mu \mathrm{l}$ Forward and Reverse $10 \mathrm{mM}$ primers, and water so that the total volume of $25 \mu \mathrm{l}$. The primers used are the primary pair ITS1 (5 'TCCTCCGCTTATTGATATGC 3') and IT S4 (5 'TCCGTAGGTGAACCTGCGG 3') which will amplify the internal transcribed spacer (ITS) DNA ribosome (rDNA) area (White at al. 1990). PCR conditions are: $94^{\circ} \mathrm{C}$ for 5 minutes 1 time, then $94^{\circ} \mathrm{C}$ for 1 minute, $56^{\circ} \mathrm{C}$ for 1 minute, and $72^{\circ} \mathrm{C}$ for 2 minutes, repeated 35 times, last $72^{\circ} \mathrm{C}$ for 10 minutes .The amplification results were electrophoresed using $1.2 \%$ agarose gel with 1x TAE buffer at 50 volt for 30 minutes. The DNA band is seen on the UV transilluminator. Generate DNA fragments measuring $\pm 600 \mathrm{bp}$. Furthermore, DNA fragments are sent to PT Macrogen Inc. Korea) to trace the nucleotide bases to determine the identity of the fungus. (on going).

\section{Inhibitory microbial inhibition test against pathogens}

The exophyte microbes found were each tested for their inhibition on the growth of pathogenic fungi by the dual culture technique (in one Petri dish each pathogenic fungus was flanked with two endophyticmicrobes). The inhibition ability can be calculated as follows (Dollar, 2001; Mojica-Marin et al., 2008):

Inhibition ability $(\%)=\frac{\mathrm{A}-\mathrm{B}}{\mathrm{A}} \times 100$

Where:

$\mathrm{A}=$ Diameter of pathogenic colonies in a single culture (mm)

$\mathrm{B}=$ Pathogenic colony diameter in dual culture (mm)

\section{Prevalence of exophytic microbes}

Determining the prevalence of exophytic microbes is based on the frequency of exophytic microbial isolates found in healthy fruit per Petri dish, divided by all isolates found 100 times. The high prevalence of isolates will determine the dominance of exophyticmicrobes in the healthy mango.

\section{Antagonistic test in vivo}

Antagonistic test in vivo exophytic microbes found by pricking fresh fruit with a spelden needle 20 times, then smeared with antagonistic fungal spores (spores of one Petri 
dish in $250 \mathrm{ml}$ of sterile aquadest), then dipped in a suspension of pathogenic fungal spores. Exophytic microbes found include:

$\mathrm{A}=$ antagonistic treatment 1 (suspense spore $5 \times 107)$

$\mathrm{B}=$ antagonistic treatment $1(5 \times 107$ spore suspension)

$\mathrm{C}=$ antagonistic treatment $2(5 \times 107$ spore suspension)

$\mathrm{D}=$ antagonistic treatment $3(5 \times 107$ spore suspension)

$\mathrm{E}=$ antagonistic treatment 4 (5x107 spore suspension)

$\mathrm{K}-\mathrm{P}=$ control without pathogens

$\mathrm{K}+\mathrm{P}=$ control with pathogens

All treatments were repeated 5 times. The experiment was designed with a randomized block design (RCBD), and after analysis of variance (ANOVA) was continued with the smallest real difference test (LSD) at 5\% level. Attack parameters measured by formulation: how many punctures attacked by the fungus are divided by the whole prick (20 $\mathrm{x})$ times $100 \%$.

\section{Results and Discussion}

\section{Pathogen identification}

Based on the results of the isolation of mango rot, two symptoms were obtained, including black symptoms at the tip of the fruit (Figure 1). The results of identification of pathogens that cause fruit rot at the ends are Lesiodiplodia theobromae, According to Prakash et al., (2011) diseases that interfere with pathogenic stem end rot are [Lasiodiplodia theobromae (Pat.) Griffon \& Moubl., Phomopsis mangiferae Ahmad, Dothiorella dominicana Sydo.] (Figure 1).

The results of the identification of pathogens by molecular techniques obtained by gene transcription of the internal transcribed spacer (ITS) DNA ribosome (rDNA) using 1.2\% agarose gel with $1 \mathrm{x}$ TAE buffer at 50 volt voltage for 30 minutes. The DNA band is seen on the UV transilluminator as seen on the electropherogram, producing a DNA fragment of $600 \mathrm{bp}$ size for $L$. theobromae (Figure 2).

Based on the results of the alignment of internal transcribed spacer (ITS) DNA rebosome (rDNA) gene sequences with the GenBank database using BalstN, fungus isolate 1 with DNA sequences as follows:

Sequence of pathogenic fungus $L$. theobromae

TGCGGAAGGATCATTACCGAGTTTTCG AGCTCCGGCTCGACTCTCCCACCCTTT GTGAACGTACCTCTGTTGCTTTGGCGG CTCCGGCCGCCAAAGGACCTTCAAACT CCAGTCAGTAAACGCAGACGTCTGATA AACAAGTTAATAAACTAAAACTTTCAA CAACGGATCTCTTGGTTCTGGCATCGA TGAAGAACGCAGCGAAATGCGATAAG TAATGTGAATTGCAGAATTCAGTGAAT CATCGAATCTTTGAACGCACATTGCGC CCCTTGGTATTCCGGGGGGCATGCCTG TTCGAGCGTCATTACAACCCTCAAGCT CTGCTTGGAATTGGGCACCGTCCTCAC TGCGGACGCGCCTCAAAGACCTCGGC GGTGGCTGTTCAGCCCTCAAGCGTAGT AGAATACACCTCGCTTTGGAGCGGTTG GCGTCGCCCGCCGGACGAACCTTCTGA ACTTTTCTCAAGGTTGACCTCGGATCA GGTAGGGATACCCGCTGAACTTAAGC ATATCAATAAGGCGGA

Comparison of the percentage similarity of 18S rRNA gene in patsirisolar fungi with some DNA sequences in GenBank using the BLAST program (Table 1).

Lasiodiplodia theobromae is a common pathogen in a large number of hosts in the 
tropics and subtropics. Collection of isolates identified as $L$. theobromae which have been studied on the basis of sequential data from the ITS region and the EF1- $\alpha$ gene (Alves et al., 2008). This fungus secretes several types of enzymes, usually including cell wall degradation and pathogenesis. An increase in global temperatures can increase fungi, such as $L$. theobromae to change their properties. Temperature modulation expresses enzymes, and this affects more markedly when fungi are grown at $37^{\circ} \mathrm{C}$ than below temperatures (Felix et al., 2018). Pathogens have been collected from $225 \mathrm{~L}$. theobromae isolates from 52 plants and from many parts of the world (Mehl et al., 2017).

\section{Esophophytic microbes and prevalence}

Exophytic microbes found in most mangoes are Rhizopus sp. with a population of 24 $\mathrm{x} 10^{2} \mathrm{cfu}$, followed by Aspergillus flavus, A. niger and Nucordia sp. (Actinomycetes) each with a population of $18 \times 10^{2} \mathrm{cfu}$, and finally the least is Streptomyces sp. (Actinomycetes) as much as $12 \times 10^{2} \mathrm{cfu}$, the highest prevalence held by Rhizopus sp. with a value of $26.67 \%$, followed by Nucordia sp., $A$. flavus and $A$. niger respectively $20 \%$ and the lowest value held by Streptomyces sp. with a value of $13.33 \%$ (Table 2; Figure 3 ).

\section{Inhibition ability of exophytic microbes on pathogens in vitro}

The highest inhibitory microbial inhibition of pathogens (A. niger) was achieved by Rhizopus sp. 1 at 3 dai (days after inoculation) of $98 \pm 0.2 \%$ and Rhizopus sp. 3 when 7 dai is $99.0 \pm 0.1 \%$. The highest inhibitory microbial inhibition against pathogens (Lasiodiplodia theobromae) was obtained from Rhizopussp. 1 of $88.89 \pm 0.3 \%$ at $4 \mathrm{hsi}$, while at 7 dai the highest was achieved by Rhizopus sp. 3 at 98 $\pm 0.2 \%$, followed by Rhizopus sp. 1 by $80 \pm$ $0.5 \%$, Rhizopus sp. 2 at $77.78 \pm 0.4 \%, A$. niger 1 at $77.78 \pm 0.3 \%$ and finally Rhizopus sp.1 at $72.22 \pm 0.2 \%$ (Table 3 ).

\section{Inhibition ability of exophytic microbes on pathogen in vivo}

The observation result of 3 dai (days after inoculation) antagonistic test in vivo, the best antagonist with pathogen ( $L$. theobromae) obtained treatment A (Rhizopus sp. 4) with the highest attack percentage of $95 \pm 4.47 \%$, followed by treatment $\mathrm{B}$ (A. niger) at $67 \pm$ 4\%, then D (Rhizopus sp. 2) and E (Rhizopus sp. 1) each attack percentage $54 \pm 3.74 \%$ and $52 \pm 2.45$, K-P treatment (control without pathogen) ) the percentage of attacks was 4.17 $\pm 4 \%$ and KP (control with pathogens) the percentage of attacks was $94 \pm 3.74 \%$, all differed markedly except for treatments $\mathrm{A}$ and $\mathrm{K}+\mathrm{P}$ (Table 4; Figure 4 and 5). There were as many as 20 species of A. niger found potentially used as biological agents against pathogens (Phytophthora palmivora) fruit rot pathogens in cocoa. Aspergillus niger is directly related to food ingredients in the media. A. niger also produces every enzyme such as enzymamase, amyloglucosidase, pectinase, cellulose, glucoside, which breaks down urea into amino acids and $\mathrm{CO} 2$ (Wulandari et al., 2016).

In this research isolate actinomycetes, from the rhizosphere of wheat plants (Triticum aestivum L.), succeeded in antagonistic activity in certain root rot fungi (Fusarium culmorum, Fusarium graminearum, Fusarium verticilloides and Bipolaris sorokiniana) (Orakci et al., 2010). Streptomyces spp. successfully isolated as endophytic it can be used as a fight against phytopathogenic fungi such as Aspergillus niger, Aspergillus flavus, Alternaria brassicicola, Botrytis cinerea, Penicillium digitatum, Fusarium oxysporum, Penicillium pinophilum, Phytophthora dresclea and Colletotrichum falcatum (Gangwar et al., 2011). 
Table.1 The similarity of isolate 1 with isolates in GenBank

\begin{tabular}{|l|c|c|}
\hline \multicolumn{1}{|c|}{ Lasiodiplodia theobromae } & Similarity percentage (\%) & $\begin{array}{c}\text { Accession } \\
\text { Number }\end{array}$ \\
\hline Lasiodiplodia theobromae isolat BTMA10 & 100 & KY657465 \\
\hline Lasiodiplodia theobromae isolat BTMA9 & 100 & KY657464 \\
\hline Lasiodiplodia theobromae isolat BTMA8 & 100 & KY657463 \\
\hline Lasiodiplodia theobromae isolat BTMA7 & 100 & KY657462 \\
\hline Lasiodiplodia theobromae isolat BTMA6 & 100 & KY657461 \\
\hline Lasiodiplodia theobromae isolat BTMA5 & 100 & KY657460 \\
\hline Lasiodiplodia theobromae isolat BTMA4 & 100 & KY657459 \\
\hline Lasiodiplodia theobromae isolat BTMA3 & 100 & KY657458 \\
\hline Lasiodiplodia theobromae isolat BTMA2 & 100 & KY657457 \\
\hline
\end{tabular}

Table.2 Exophytic microbial types and populations found in healthy mangoes

\begin{tabular}{|l|l|c|c|}
\hline No. & Name of microbes & Population ( $\mathbf{~ 1 0} \mathbf{2}$ cfu) & Prevalence (\%) \\
\hline $\mathbf{1}$ & Rhizopus sp. & 24 & 26,67 \\
\hline $\mathbf{2}$ & Nucordia sp. (Actinomycetes) & 18 & 20 \\
\hline $\mathbf{3}$ & Streptomyces sp. (Actinomycetes) & 12 & 13,33 \\
\hline $\mathbf{4}$ & Aspergillus flavus & 18 & 20 \\
\hline $\mathbf{5}$ & Aspergillus niger & 18 & 20 \\
\hline Total & & $\mathbf{9 0}$ & $\mathbf{1 0 0}$ \\
\hline
\end{tabular}

Table.3 Inhibition ablity of exophytic microbes on L. theobromae

\begin{tabular}{|c|c|c|c|}
\hline \multirow{2}{*}{$\begin{array}{l}\text { Number } \\
\text { of isolate }\end{array}$} & \multirow[t]{2}{*}{ Microbes name } & \multicolumn{2}{|c|}{ L. theobromae } \\
\hline & & $\begin{array}{c}\text { Inhibition ability } 4 \\
\text { dai* }(\%)\end{array}$ & $\begin{array}{c}\text { Inhibition ability } 7 \\
\text { dai* }(\%)\end{array}$ \\
\hline 1 & Rhizopus sp.1 & $88,89 \pm 0,3$ & $72,22 \pm 0,2$ \\
\hline 2 & Nucordi sp. (Actinomycetes) 1 & - & - \\
\hline 3 & Streptomyces sp. (Actinomycetes) 1 & - & - \\
\hline 4 & Aspergillus flavus 1 & - & - \\
\hline 5 & A. niger 1 & $83,33 \pm 0,4$ & $77,78 \pm 0,3$ \\
\hline 6 & A.niger 2 & - & - \\
\hline 7 & Rhizopus sp. 2 & $83,33 \pm 0,5$ & $80 \pm 0,5$ \\
\hline 8 & Nucordia sp. (Actinomycetes) 2 & - & - \\
\hline 9 & A.flavus 2 & - & - \\
\hline 10 & Rhizopus sp.3 & $77.78 \pm 0,6$ & $77,78 \pm 0,4$ \\
\hline 11 & A.flavus3 & - & - \\
\hline 12 & Streptomyces sp. (Actinomycetes) 2 & - & - \\
\hline 13 & Rhizopus sp.4 & $83,33 \pm 0,3$ & $98 \pm 0,2$ \\
\hline 14 & Nucordia sp. (Actinomycetes) 3 & - & - \\
\hline 15 & Rhizopus sp. 5 & - & - \\
\hline
\end{tabular}

*dai = days after inoculation 
Table.4 The best inhibitory test results in vivo are antogonists against pathogens (L.theobromae)

\begin{tabular}{|l|l|c|c|c|}
\hline Treatment & Name of microbes & $\begin{array}{l}\text { Diseases } \\
\text { incidence } \mathbf{( \% )}\end{array}$ & \multicolumn{2}{|c|}{ Notation } \\
\cline { 3 - 5 } & & $95 \pm 4,47$ & A & A \\
\hline A & Rhizopus sp. 4 & $67 \pm 4$ & B & B \\
\hline B & A. niger 1 & $14 \pm 3,74$ & E & E \\
\hline C & Rhizopus sp. 3 & $54 \pm 3,74$ & C & C \\
\hline D & Rhizopus sp. 2 & $52 \pm 2,45$ & D & D \\
\hline E & Rhizopus sp. 1 & $4,17 \pm 4$ & F & F \\
\hline K-P & Control without pathogen & $94 \pm 3,74$ & A & A \\
\hline K+P & Control with pathogen & & & \\
\hline
\end{tabular}
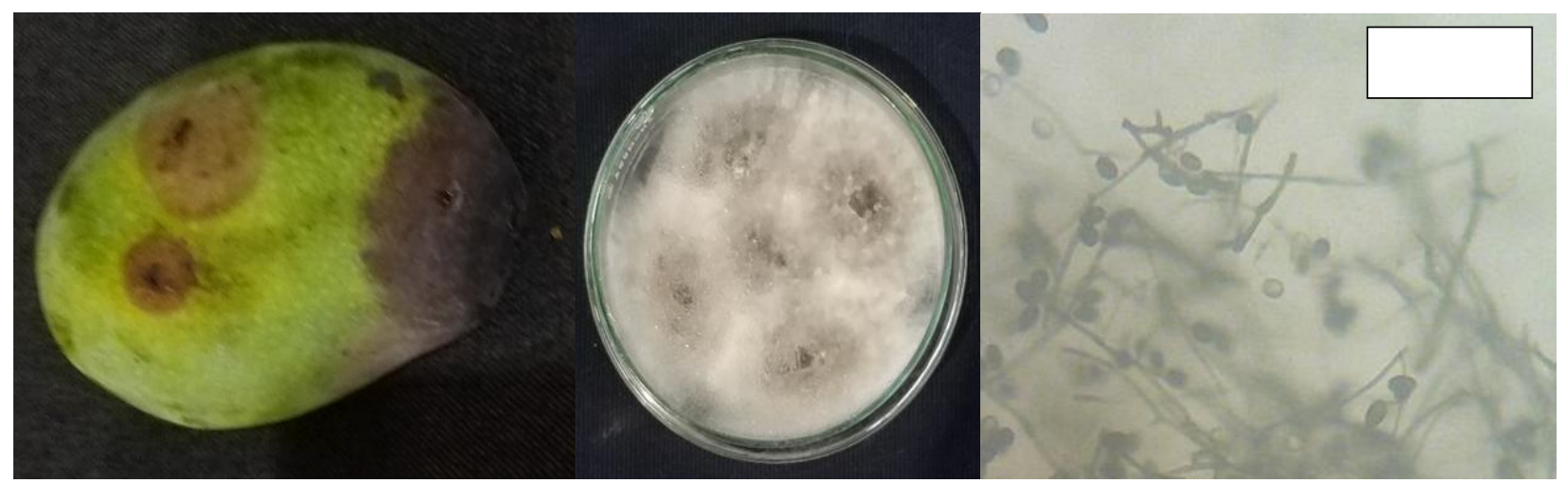

Figure.1 Symptoms of mango rot disease (A), (B) mycelium growth in Petri dishes, and (C) for conidia and conidiophores of fungal pathogens (Lesiodiplodia theobromae)

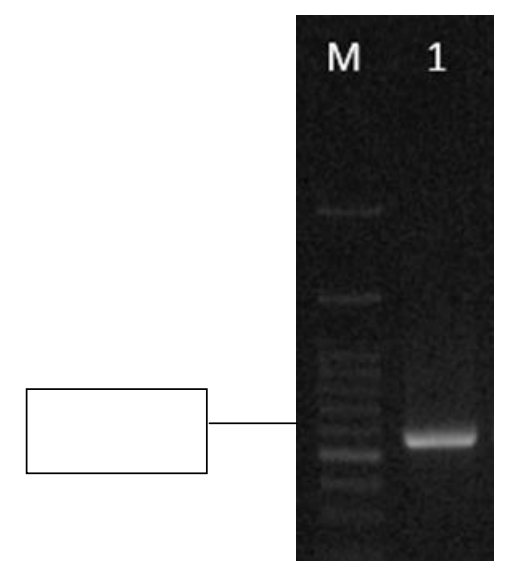

Fig.2 Pathogen L. Theobromae Amplikon gen 18S rRNA.

M. DNA Ladder 100 bp 


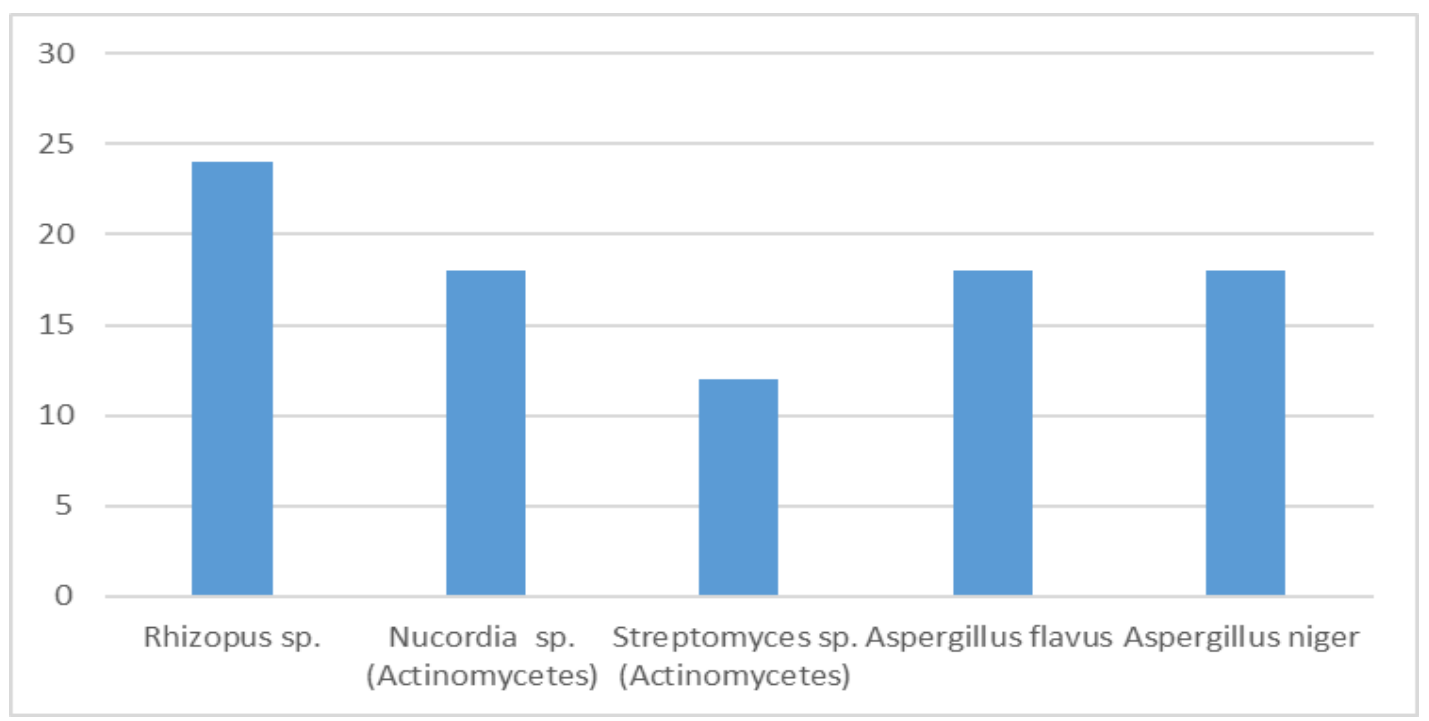

Figure.3 Types of exophytic microbes derived from healthy mangoes

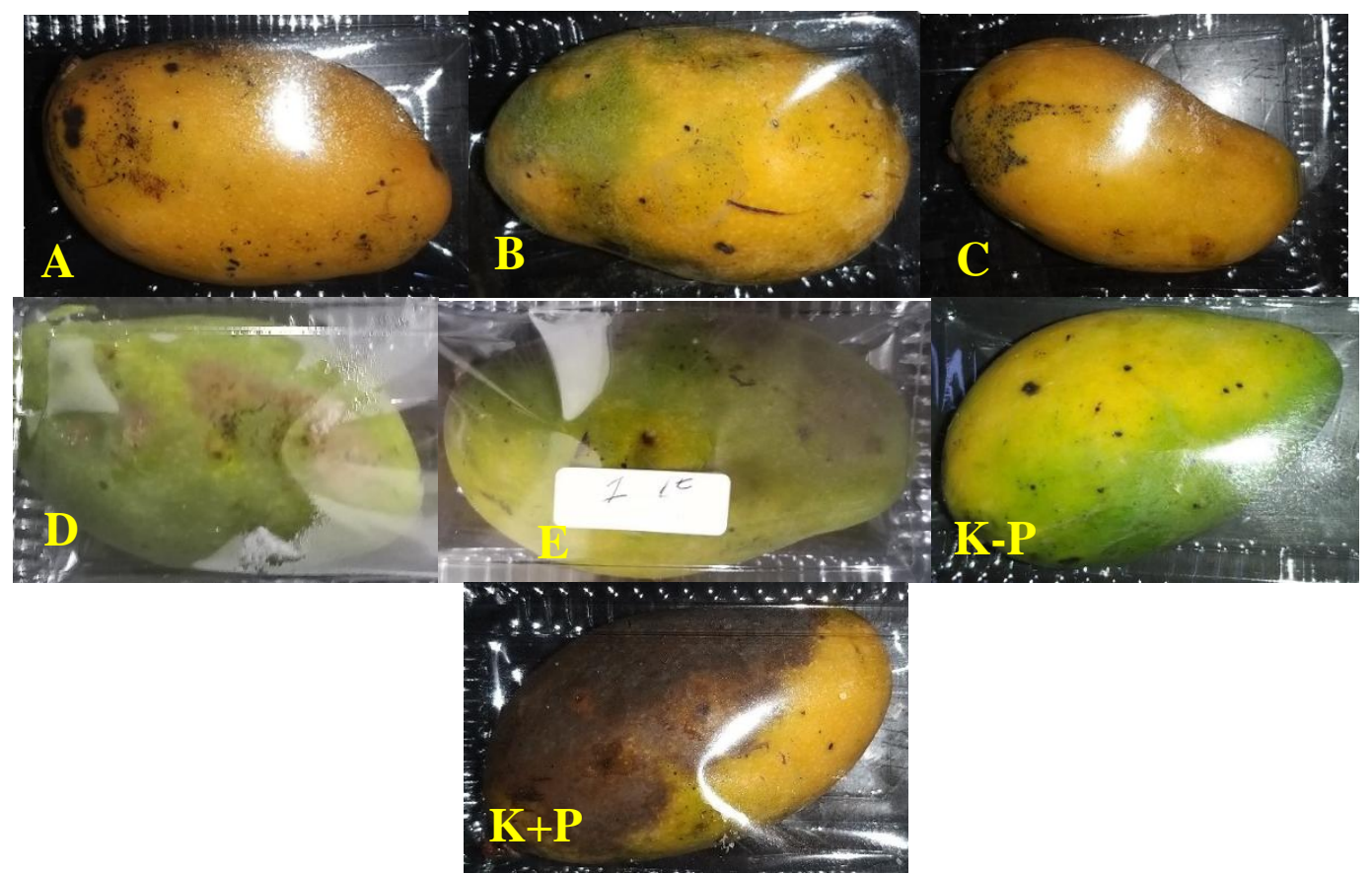

Figure.4 \& 5 In vivo antagonist test is the best antagonist with pathogen (L. theobromae), $(\mathrm{A}=$ Rhizopussp. 4, $\mathrm{B}=$ A. niger $1, \mathrm{C}=$ Rhizopus sp. 3, $\mathrm{D}=$ Rhizopus sp. 2, $\mathrm{E}=$ Rhizopus $\mathrm{sp} .1$, $\mathrm{K}-\mathrm{P}=$ control without pathogen and $\mathrm{K}+\mathrm{P}=$ control with pathogen)

Rhizopus sp. can suppress the growth of Aspergillus flavus toxigenic molds and degrade aflatoxin. Rhizopus sp. can also produce compounds that can inhibit pathogenic bacteria and function as antioxidants. Rhizopus sp. absorb some mineral elements and convert them into organic minerals so that they can increase the absorption of minerals in the body better. Utilization of fermented feed ingredients by Rhizopus sp. in cattle showing better results compared to without fermentation. Rhizopus sp. it is also very potential to be applied as supplement feed for livestock (Endrawati and Kusumaningtyas, 2017). Sixteen endophytic fungi have been able to be identified as 
Acremonium sp., Aspergillus spp., Cephalosporium sp., Fusarium spp., Helicocephalum spp., Penicillium spp., Rhizopus sp., and 4 species were not able to be identified. Antagonistic test results of the percentage of inhibition ranged from $36.93 \%$ - 100\%. Statistical analysis shows that endophytic fungi are able to control $P$. infestans (Wulandari et al., 2014).

Based on the results and discussion above, it can be concluded as follows:the pathogen found to cause fruit rot disease in mangoes is Lesiodiplodia theobromae. Exophyte microbes found in healthy mangoes include: Rhizopus sp. the number of colonies $24 \mathrm{x}$ $10^{2} \mathrm{cfu}$, while Nucordia sp., A. flavus, and A. niger with colonies $18 \times 10^{2} \mathrm{cfu}$ each, and Streptomyces sp. with a colony of $12 \mathrm{x}$ $10^{2} \mathrm{cfu}$. Rhizopus sp. Microbial inhibitory test results: 1 and Rhizopus sp. 4 when 4 dai (days after inoculation) and 7 dai against pathogens (L. theobromae). The results of antagonistic inhibition test on pathogens ( $L$. theobromae) in vivo obtained the highest by the treatment of C (Rhizopus sp. 3) which was very significantly different from $\mathrm{K}+\mathrm{P}$ (control with pathogens).

\section{Acknowledgements}

Authors wish to thank to the Rector of Udayana University for their assistance and the opportunity given so that research can be resolved, Dean of the Faculty of Agriculture, Udayana University, and Chairman of the Institute for Research and Community Service Udayana University, for their help and cooperation so that research can be funded to completion.

\section{References}

Alves, A., P.W. Crous, A. Correia, and A.J.L. Phillips. 2008. Morphological and molecular data reveal cryptic speciation in Lasiodiplodia theobromae. Fungal Diversity 28: 1-13.

Barnett, H.L. and B.B. Hunter. 1998. Illustrated Genera of Imperfect Fungi. APS Press. The American Phytopathological Sociey. St Paul, Minnesota.

Dolar, F.S. 2001. Antagonistic effect of Aspergillus melleus Yukawa on soilborne pathogens of Chickpea. Tarim Bilimleri Dergisi, 8(2): 167-170.

Endrawati, D., dan E. Kusumaningtyas. 2017. BeberapaFungsiRhizopusspdalamMenin gkatkanNilaiNutrisiBahanPakan. Wartaz oa 27(2): 081-088.

Felix, C., S. Liborio, M. Nunes, R. Felix, A.S. Duarte, A. Alves, and A.C. Esteves. 2018. Lasiodiplodia theobromae as a produser of biotechnologically relevant enzymes. International Journal of Molecular Science 19(29): 1-15.

Gangwar, M., S. DograandN. Sharma. 2011. Antagonistic Bioactivity of Endophytic Actinomycetes Isolated from Medicinal Plants. Journal of Advanced Laboratory Research in Biology2(4): 154-157.

Indrawati. G., R.A. Samson, K. Van den Tweel-Vermeulen, A. Oetari dan I. Santoso. 1999. Pengenalan Kapang Tropik Umum. Yayasan Obor Indonesia. Universitas Indonesia (University of Indonsia Culture Collection) Depok, Indonsia dan Centraalbureau voor Schirmmelcultures, Baarn, The Netherlands

Langvad, F. 1980. A simple and rapid method for qualitative and quantitative study of the fungal flora of leave. Canadian Journal of Baotany 26: 666-670.

Leben, C. 1965. Epiphytic micro-organisms in relation to plant diseases. Annual Review of Phytopathology 2: 209-230.

Mehl, J., M.J. Wingfield, J. Roux, and B. Slippers. 2017. Invasive everymhere? Phylogeographic analysis of the globally distributed tree pathogen 
Lasiodiplodia theobromae. Forests 8(145): 1-22.

Mojica-Marin, V., H. A. Luna-Olvera, C. Fco, Sandoval-Coronado, B. PereyraAlférez, H. Lilia, Morales-Ramos, E. Carlos, Hernández-Luna and G. O. Alvarado-Gomez. 2008. Antagonistic activity of selected strains of Bacillus thuringiensis against Rhizoctonia solani of chili pepper. African Journal of Biotechnology, 7 (9): 1271-1276.

Orakçı G.E., M.Yamaç, M. J. Amoroso and S. A.Cuozzo. 2010. Selection of antagonistic actinomycete isolates as biocontrol agents against root-rot fungi. Fresenius Environmental Bulletin 19(3): 417-424.

Pitt, J.I. and A.D. Hocking. 1997. Fungi and Food Spoilage. Blackie Avademic and Professional. Second Edition. LondonWeinhein-New York-Tokyo-MelbouneMadras.

Prakash, O.M., A.K. Misraand and P.K. Shukla. 2011. Post-harvest diseases of mango and their management. Global Conference on Augmenting Production and Utulization of Mango: Biotic and Abiotic Stress. P: 137-144.
Samson, R.A., E.S. Hoekstra, and C. A.N. Van Oorschot. 1981. Introduction to Food-Borne Fungi. Centraalbureau Voor-Schimmel cultures. Institute of The Royal Netherlands. Academic of Arts and Sciences.

Sudarma, I M., N. N. Darmiati and N.W. Suniti. 2019. Fungus and Actinomycetes Diversity of Exophytic and Endophytic in Red Grape and its Inhibition Ability to Pathogen Aspergillus niger (Caused Rot Fruit Grape). Int.J.Curr.Microbiol.App.Sci 8(10): 2442-2451.

Wulandari, D., L. Sulistyawati, dan A. Muhibuddin. 2014. Keanekaragaman Jamur Endofitpada Tanaman Tomat (Lycopersicum esculentum Mill.) dan Kemampuan Antagonisnya Terhadap PhytophthoraInfestans, Jurnal HPT 2(1): 110-118.

Wulandari, D.E., Asrul, dan I. Lakani. 2016. Seleksi Jamur Antagonis Aspergillus Niger Dari Beberapa Lahan Perkebunan Kakao Untuk Mengendalikan Phytophthora Palmivora. J. Agroland., 23 (3): $233-242$.

\section{How to cite this article:}

I Made Sudarma, Ni Wayan Suniti and dan Ni Nengah Darmiati. 2020. Use of Exophytic Microbial on the Control of Fruit Rot Disease of Mango (Lesiodiplodia theobromae). Int.J.Curr.Microbiol.App.Sci. 9(04): 845-854. doi: https://doi.org/10.20546/ijcmas.2020.904.102 